\title{
Effect of Row Spacing and Nitrogen Levels on Growth and Yield of Dill (Anethum graveolens L.)
}

\author{
Umesh Kadbe, I. S. Naruka, R. P. S. Shaktawat*, O. P. Singh, S. S. Kushwah and Jyoti Kanwar
}

Dept. of Plantation, Spices, Medicinal and Aromatic Crops, RVSKVV College of Horticulture Mandsaur, Madhya Pradesh (458 001), India

\section{Article History}

Manuscript No. AR1598

Received in $18^{\text {th }}$ May, 2016

Received in revised form $20^{\text {th }}$ July, 2016

Accepted in final form $2^{\text {nd }}$ August, 2016

\section{Correspondence to}

*E-mail: rpssbkn1@rediffmail.com

\section{Keywords}

Dill, growth, nitrogen, spacing, quality, yield

\begin{abstract}
An experiment was conducted at the Horticulture Research Farm, RVSKVV College of Horticulture, Mandsaur (Madhya Pradesh) during the rabi season of 2013-2014 to study the effect of row spacing and nitrogen levels on the growth and yield of dill (Anethum graveolens L.). The experiment consisted of 3 levels of row spacing $(40 \times 10$ $\mathrm{cm}^{2}, 50 \times 10 \mathrm{~cm}^{2}$ and $\left.60 \times 10 \mathrm{~cm}^{2}\right)$ and 4 levels of nitrogen $(0,25,50$ and $75 \mathrm{~kg} \mathrm{~N}$ $\left.\mathrm{ha}^{-1}\right)$. These treatments were evaluated under factorial Randomized Block Design with three replications. Different levels of row spacing and nitrogen significantly affect the plant height, branches, umbels, umbellate, seeds umbel ${ }^{-1}$, days to $50 \%$ flowering, chlorophyll content in leaves, fresh and dry weight of plant, test weight, seed, straw and biological yield, harvest index, gross return, net return and B:C ratio of dill. Among various levels of row spacing tried, $50 \times 10 \mathrm{~cm}^{2}$ row spacing exhibited significantly higher growth and yield attributes and recorded significantly maximum seed yield of $15.04 \mathrm{q} \mathrm{ha}^{-1}$ which was $42.56 \%$ higher as compare to row spacing of $40 \times 10 \mathrm{~cm}^{2}$. Among the various nitrogen levels tried, $75 \mathrm{~kg} \mathrm{~N} \mathrm{ha}^{-1}$ exhibited significant maximum growth, yield attributes and quality of dill. Further treatment observed significant higher seed yield of $14.48 \mathrm{q} \mathrm{ha}^{-1}$ which was $57.22 \%$ higher with $\mathrm{B}: \mathrm{C}$ ratio of 3.08 in comparison to other nitrogen levels (control).
\end{abstract}

\section{Introduction}

Dill, popularly known as sowa, is one of the oldest cultivated seed spices of India. Dill seed are used, both as such and in ground form for its application as a condiment in soups, salads, processed meat, sausages, sauces and pickling. Ground seed is an ingredient of seasoning. Both seed and oils are used in formulation of various ayurvedic medicines. The gripe water is prepared from its seed, which is used to improve digestion and control vomiting in infants and children. In India dill seed is cultivated in about 22 thousand ha with production of about 23.6 thousand $\mathrm{mt}$ (DASD, 2012). It is cultivated commercially in Rajasthan, Gujarat, Maharashtra, Andhra Pradesh and Madhya Pradesh states of India. Spacing is an important factor for better growth and yield of the plant. Optimum number of plants is required unit ${ }^{-1}$ area to utilize efficiently the available production factors such as water, nutrient, light and $\mathrm{CO}_{2}$. Maximum exploitation of these factors is achieved when the plant population puts forth maximum pressure on all the factors of production (Mehta et al., 2012). Nitrogen is another most important factor for proper growth, yield and quality of crop.
It's a constituent of proteins, enzymes, hormones, vitamins, alkaloid, chlorophyll etc. Plant growth is adversely affected due to deficiency of nitrogen as it is a constituent of enzyme, chlorophyll and proteins (Reddy and Reddi, 2002). Keeping the above fact in view, this experiment was conducted for knowing the optimum row spacing with the nitrogen fertilization for achieving the higher productivity of this important seed spice crop.

\section{Materials and Methods}

The experiment was conducted at the Horticulture Research Farm, College of Horticulture, Mandsaur during the year 2013-2014. The soil of the experimental field was light black loamy in texture with low nitrogen $\left(243.2 \mathrm{~kg} \mathrm{ha}^{-1}\right)$, medium in phosphorus (19.75 $\left.\mathrm{kg} \mathrm{ha}^{-1}\right)$ and high in potassium $\left(448.0 \mathrm{~kg} \mathrm{ha}^{-}\right.$ $\left.{ }^{1}\right)$ and alkaline in reaction ( $\left.\mathrm{pH} 7.2\right)$. The experiment consisted of 3 levels of row spacing $40 \times 10 \mathrm{~cm}^{2}\left(\mathrm{~S}_{1}\right), 50 \times 10 \mathrm{~cm}^{2}\left(\mathrm{~S}_{2}\right)$ and $60 \times 10 \mathrm{~cm}^{2}\left(\mathrm{~S}_{3}\right)$ and 4 levels of nitrogen $0 \mathrm{~kg} \mathrm{ha}^{-1}\left(\mathrm{~N}_{1}\right), 25$ $\mathrm{kg} \mathrm{N} \mathrm{ha}^{-1}\left(\mathrm{~N}_{2}\right), 50 \mathrm{~kg} \mathrm{~N} \mathrm{ha}^{-1}\left(\mathrm{~N}_{3}\right)$, and $75 \mathrm{~kg} \mathrm{~N} \mathrm{ha}^{-1}\left(\mathrm{~N}_{4}\right)$. These treatments were evaluated in factorial RBD design with three replications. The sowing of crop was done on $22^{\text {nd }}$ November, 
2013 and harvested on $30^{\text {th }}$ April, 2014. The seeds were treated with carbendezim@3 $\mathrm{g} \mathrm{kg}^{-1}$ seed and then sown at a depth of $5 \mathrm{~cm}$ in row spaced as treatment ${ }^{-1}$ using $5 \mathrm{~kg}$ seed ha- $\mathrm{h}^{-1}$ of cultivar NRCSS AD-1. FYM @ $10 \mathrm{tha}^{-1}$ was incorporated in the soil one month before sowing and a uniform dose of $40 \mathrm{~kg}$ $\mathrm{P}_{2} \mathrm{O}_{5}$ and $20 \mathrm{~kg} \mathrm{~K}_{2} \mathrm{O} \mathrm{ha}^{-1}$ was applied as basal. The oil content was estimated by using essential oil distillation assembly (A.O.A.C. 1995).

\section{Results and Discussion}

\subsection{Effect of row spacing}

\subsubsection{Growth attributes}

It was observed that plants under closer spacing $\left(40 \times 10 \mathrm{~cm}^{2}\right)$ attained greater plant height as compared to the plants that were grown at other spacing $\left(50 \times 10 \mathrm{~cm}^{2}\right.$ and $\left.60 \times 10 \mathrm{~cm}^{2}\right)$ (Table 1). However, fresh and dry weight of plant and number of branches were improving due to increase in spacing from $50 \times 10 \mathrm{~cm}^{2}$ to $60 \times 10 \mathrm{~cm}^{2}$. Significant increase in plant height right from early stage of crop growth under closer spacing seem to be due to mutual shading because of dense population. This might have decreased the availability of light to the plants. The reduced light intensity at the base of the plant stem might have accelerated elongation of lower internodes resulting in greater plant height. The results indicated that crop raised under optimum row spacing $\left(50 \times 10 \mathrm{~cm}^{2}\right)$ recorded highest number of branches, fresh and dry weight of plant. Significant improvement in aforesaid parameters due to increase in spacing or in other words reduction in plant population unit ${ }^{-1}$ area could be ascribed to availability of more area plant ${ }^{-1}$ which implied that individual plant at wider spacing received higher growth inputs (sunlight, water and nutrients) with least competition as compared to the plants grown under closer spacing. Thus greater inputs under spacing $\left(50 \times 10 \mathrm{~cm}^{2}\right.$ and $\left.60 \times 10 \mathrm{~cm}^{2}\right)$ resulted in profuse branching which in turn might have helped in larger canopy development and delayed plants to attain reproductive phase. The larger canopy development associated with profuse branching has increased interception, absorption and utilization of solar energy resulting in formation of higher photosynthates and finally dry matter plant ${ }^{-1}$. Significant improvement in growth with increase in spacing is in close conformity with the findings of Meena et al. (2013); Mehta et al. (2012) in dill crop Bagari et al. (2010) in fennel and Naruka et al. (2012) in ajowan.

\subsubsection{Yield and yield attributes}

It was observed that increase in spacing from $40 \times 10 \mathrm{~cm}^{2}$ to $50 \times 10 \mathrm{~cm}^{2}$ significantly improved various yield attributes of the crop. Days to $50 \%$ flowering, number of umbels plant ${ }^{-1}$, number of umbellet umbel ${ }^{-1}$, test weight were improved due to each increase in spacing and the maximum value for these estimates were obtained at the spacing $\left(50 \times 10 \mathrm{~cm}^{2}\right)$, while least under closer spacing $\left(40 \times 10 \mathrm{~cm}^{2}\right)$. However, results in respect to productivity revealed that crop grown under wider spacing $\left(50 \times 10 \mathrm{~cm}^{2}\right)$ produced higher seed yield $\left(15.04 \mathrm{q} \mathrm{ha}^{-1}\right)$, straw

\begin{tabular}{|c|c|c|c|c|c|c|c|c|c|c|c|}
\hline \multirow[t]{2}{*}{ Treatments } & \multicolumn{3}{|c|}{ Plant height $(\mathrm{cm})$} & \multirow[t]{2}{*}{$\begin{array}{c}\text { Branches } \\
\text { plant }^{-1} \text { at } \\
\text { harvest }\end{array}$} & \multirow[t]{2}{*}{$\begin{array}{l}\text { Umbels } \\
\text { plant }^{-1}\end{array}$} & \multirow[t]{2}{*}{$\begin{array}{l}\text { Umbellet } \\
\text { umbel }^{-1}\end{array}$} & \multirow[t]{2}{*}{$\begin{array}{l}\text { Seeds } \\
\text { umbel }^{-1}\end{array}$} & \multirow[t]{2}{*}{$\begin{array}{c}\text { Days } \\
\text { to } 50 \% \\
\text { flowering }\end{array}$} & \multirow{2}{*}{$\begin{array}{c}\text { Essential } \\
\text { oil } \\
\text { content } \\
\text { in seed } \\
(\%)\end{array}$} & \multicolumn{2}{|c|}{$\begin{array}{c}\text { Chlorophyll } \\
\text { content in leaves } \\
\text { (SPAD) }\end{array}$} \\
\hline & $\begin{array}{c}40 \\
\text { DAS }\end{array}$ & $\begin{array}{c}80 \\
\text { DAS }\end{array}$ & $\begin{array}{c}120 \\
\text { DAS }\end{array}$ & & & & & & & $\begin{array}{c}60 \\
\text { DAS }\end{array}$ & $\begin{array}{c}90 \\
\text { DAS }\end{array}$ \\
\hline \multicolumn{12}{|c|}{ Row spacing } \\
\hline $\mathrm{S}_{1}(40 \times 10)$ & 19.82 & 71.06 & 158.39 & 35.42 & 44.05 & 29.88 & 390.66 & 92.5 & 1.71 & 3.49 & 1.31 \\
\hline $\mathrm{S}_{2}(50 \times 10)$ & 17.27 & 69.22 & 152.47 & 41.70 & 60.23 & 41.45 & 494.33 & 80.08 & 3.42 & 5.02 & 2.02 \\
\hline $\mathrm{S}_{3}(60 \times 10)$ & 14.79 & 66.56 & 141.55 & 39.03 & 54.36 & 39.65 & 450.00 & 82.75 & 2.64 & 4.69 & 1.80 \\
\hline $\mathrm{SEm} \pm$ & 0.25 & 0.31 & 0.54 & 0.25 & 0.67 & 1.22 & 5.74 & 0.51 & 0.06 & 0.13 & 0.04 \\
\hline $\begin{array}{l}\mathrm{CD} \\
(p=0.05)\end{array}$ & 0.73 & 0.93 & 1.60 & 0.75 & 1.99 & 3.58 & 16.86 & 1.50 & 0.19 & 0.40 & 0.13 \\
\hline \multicolumn{12}{|c|}{ Nitrogen levels $\left(\mathrm{kg} \mathrm{ha}^{-1}\right)$} \\
\hline $\mathrm{N}_{1}(0)$ & 15.94 & 66.76 & 145.15 & 37.00 & 47.25 & 33.64 & 387.67 & 80.22 & 2.15 & 3.57 & 1.50 \\
\hline $\mathrm{N}_{2}(25)$ & 16.61 & 68.26 & 149.60 & 37.89 & 51.38 & 34.93 & 439.78 & 82.89 & 2.47 & 4.17 & 1.61 \\
\hline $\mathrm{N}_{3}(50)$ & 17.67 & 69.75 & 151.52 & 39.20 & 53.89 & 37.36 & 465.11 & 87.78 & 2.73 & 4.69 & 1.79 \\
\hline $\mathrm{N}_{4}(75)$ & 18.96 & 71.02 & 156.97 & 40.79 & 59.03 & 42.04 & 487.44 & 89.56 & 3.02 & 5.19 & 1.96 \\
\hline $\mathrm{SEm} \pm$ & 0.29 & 0.36 & 0.63 & 0.29 & 0.78 & 1.40 & 6.63 & 0.59 & 0.07 & 0.16 & 0.05 \\
\hline $\begin{array}{l}\mathrm{CD} \\
(p=0.05)\end{array}$ & 0.85 & 1.07 & 1.85 & 0.87 & 2.30 & 4.13 & 19.46 & 1.73 & 0.22 & 0.46 & 0.15 \\
\hline
\end{tabular}


yield $\left(25.19 \mathrm{q} \mathrm{ha}^{-1}\right)$ and biological yield $\left(45.15 \mathrm{q} \mathrm{ha}^{-1}\right)$ compared to other spacing $\left(40 \times 10 \mathrm{~cm}^{2}\right.$ and $\left.60 \times 10 \mathrm{~cm}^{2}\right)$.

Marked improvement in yield attributes of the crop with increase in spacing appear to be on account of vigorous growth of the plants as evident from profuse branching and higher biomass accumulation plant ${ }^{-1}$. The profuse branching seems to have led to greater initiation of flowering and adequate supply of metabolites due to the increase in biomass plant ${ }^{-1}$ might have helped in retention of flower thereby greater seed formation and seed growth. This was ultimately reflected in increased seed yield plant ${ }^{-1}$. Under the closer spacing growth and development of yield components and number of plants positively interacted with each other and might be due to increased biomass resulting in higher seed yield. These findings in close conformity with Naruka et al. (2012) in ajowan and Mehta et al. (2012) in dill crop.

\subsubsection{Quality attributes}

Significantly higher chlorophyll content of leaves and essential oil content of seed under spacing $\left(50 \times 10 \mathrm{~cm}^{2}\right)$ could be ascribed due to availability of large space plant ${ }^{-1}$ resulted in profuse vegetative growth and delayed plants to attain reproductive growth. The similar results have also been reported by Bist et al. (2000) in dill.

\subsection{Effect of nitrogen}

\subsubsection{Growth attributes}

Significantly higher plant height at 40, 80 and 120 DAS, number of branches at harvest and days to $50 \%$ flowering was recorded as a result of higher levels of $\mathrm{N}$ fertilizer. Higher levels of $\mathrm{N}$ may be attributes to better nutritional environment in the root zone as well as in the plant system. It is an established fact that nitrogen is one of the essential constituent required for the synthesis of protein, chlorophyll and other organic compounds of physiological significance in the plant system. Since, in the plant system most of the nitrogen accumulated in the reproductive structure is translocated from vegetative parts, the assumption seems to be justified that nitrogen application lead to increased nitrogen content in the plants right from stage of crop growth. Thus, increased endogenous level of nitrogen in plant by virtue of its increased availability in the soil medium and there after efficient absorption and translocation in various growths by way of active cell division and elongation resulting in greater plant height, number of branches at harvest. The findings of this investigation are in close conformity with those of Krishnamoorthy and Madalgiri (2000); Naruka et al. (2012) in ajowan.

\subsubsection{Yield and yield attributes}

Data on yield components of the crop under influence of $\mathrm{N}$ application indicates that increasing level of Nitrogen up to $75 \mathrm{~kg} \mathrm{~N} \mathrm{ha}^{-1}$ significantly improved fresh and dry weight of plant at 40, 80 and 120, number of umbels plant ${ }^{-1}$, number of umbellet umbel ${ }^{-1}$, number of seed umbel ${ }^{-1}$, test weight $(\mathrm{g})$, seed yield, straw yield, biological yield and harvest index $\%$ (Table 2). Application of $75 \mathrm{~kg} \mathrm{~N} \mathrm{ha}^{-1}$ significantly increased

\begin{tabular}{|c|c|c|c|c|c|c|c|c|c|c|c|c|c|c|}
\hline \multirow[t]{2}{*}{$\begin{array}{l}\text { Treat- } \\
\text { ments }\end{array}$} & \multicolumn{3}{|c|}{$\begin{array}{l}\text { Fresh weight of plant } \\
(\mathrm{g})\end{array}$} & \multicolumn{3}{|c|}{$\begin{array}{l}\text { Dry weight of plant } \\
(\mathrm{g})\end{array}$} & \multirow{2}{*}{$\begin{array}{l}\text { Test } \\
\text { weight } \\
\text { (g) }\end{array}$} & \multirow{2}{*}{$\begin{array}{c}\text { Straw } \\
\text { yield } \\
(\mathrm{q} \mathrm{ha-1)}\end{array}$} & \multirow{2}{*}{$\begin{array}{c}\text { Bio- } \\
\text { logical } \\
\text { yield } \\
\left(\mathrm{q} \mathrm{ha}^{-1}\right)\end{array}$} & \multirow{2}{*}{$\begin{array}{c}\text { Seed } \\
\text { yield } \\
(\mathrm{q} \mathrm{ha-1})\end{array}$} & \multirow{2}{*}{$\begin{array}{c}\text { Har- } \\
\text { vest } \\
\text { index } \\
(\%)\end{array}$} & \multirow{2}{*}{$\begin{array}{c}\text { Gross } \\
\text { return ₹ } \\
\text { ha }^{-1}\end{array}$} & \multirow{2}{*}{$\begin{array}{l}\text { Net } \\
\text { return } \\
₹ \text { ha }^{-1}\end{array}$} & \multirow[t]{2}{*}{$\begin{array}{l}\mathrm{B}: \mathrm{C} \\
\text { ratio }\end{array}$} \\
\hline & $\begin{array}{c}40 \\
\text { DAS }\end{array}$ & $\begin{array}{c}80 \\
\text { DAS }\end{array}$ & $\begin{array}{c}120 \\
\text { DAS }\end{array}$ & $\begin{array}{c}40 \\
\text { DAS }\end{array}$ & $\begin{array}{c}80 \\
\text { DAS }\end{array}$ & $\begin{array}{c}120 \\
\text { DAS }\end{array}$ & & & & & & & & \\
\hline \multicolumn{15}{|c|}{ Row spacing } \\
\hline $\mathrm{S}_{1}(40 \times 10)$ & 5.09 & 63.39 & 155.30 & 1.20 & 5.08 & 65.89 & 4.09 & 20.76 & 31.31 & 10.55 & 33.38 & 52587 & 29690 & 2.28 \\
\hline $\mathrm{S}_{2}(50 \times 10)$ & 7.00 & 69.89 & 264.96 & 1.45 & 8.96 & 82.52 & 5.82 & 25.19 & 45.15 & 15.04 & 33.21 & 75220 & 52323 & 3.27 \\
\hline $\mathrm{S}_{3}(60 \times 10)$ & 6.27 & 67.87 & 261.92 & 1.36 & 7.66 & 76.93 & 5.28 & 24.16 & 38.62 & 11.40 & 29.37 & 57025 & 34127 & 2.47 \\
\hline $\mathrm{SEm} \pm$ & 0.13 & 0.31 & 0.45 & 0.01 & 0.10 & 0.56 & 0.20 & 0.36 & 0.29 & 0.18 & 0.48 & 906.8 & 906.8 & 0.04 \\
\hline $\begin{array}{l}\mathrm{CD} \\
(p=0.05)\end{array}$ & 0.40 & 0.92 & 1.32 & 0.051 & 0.29 & 1.66 & 0.60 & 1.07 & 0.86 & 0.54 & 1.42 & 2659.5 & 2659.7 & 0.11 \\
\hline \multicolumn{15}{|c|}{ Nitrogen levels $\left(\mathrm{kg} \mathrm{ha}^{-1}\right)$} \\
\hline $\mathrm{N}_{1}(0)$ & 5.27 & 64.83 & 223.93 & 1.25 & 6.68 & 71.60 & 4.27 & 17.62 & 36.05 & 9.21 & 25.73 & 46027 & 23627 & 2.05 \\
\hline $\mathrm{N}_{2}(25)$ & 6.02 & 66.10 & 226.50 & 1.32 & 7.02 & 73.94 & 4.69 & 21.91 & 38.15 & 11.92 & 31.16 & 59605 & 36845 & 2.61 \\
\hline $\mathrm{N}_{3}(50)$ & 6.48 & 67.72 & 228.51 & 1.37 & 7.41 & 75.94 & 5.05 & 26.14 & 39.06 & 13.74 & 35.30 & 68694 & 45641 & 2.97 \\
\hline $\mathrm{N}_{4}(75)$ & 6.75 & 69.56 & 230.66 & 1.42 & 7.85 & 78.98 & 6.26 & 27.84 & 40.20 & 14.48 & 35.77 & 72116 & 48738 & 3.08 \\
\hline $\operatorname{SEm} \pm$ & 0.15 & 0.36 & 0.52 & 0.02 & 0.11 & 0.65 & 0.23 & 0.42 & 0.34 & 0.20 & 0.56 & 1047.0 & 1047.1 & 0.04 \\
\hline $\begin{array}{l}\mathrm{CD} \\
(p=0.05)\end{array}$ & 0.46 & 1.06 & 1.52 & 0.059 & 0.34 & 1.91 & 0.69 & 1.23 & 0.99 & 0.59 & 1.64 & 3071.0 & 3071.1 & 0.13 \\
\hline
\end{tabular}


the seed yield ( $14.48 \mathrm{q} \mathrm{ha}^{-1}$ ) by $57.22 \%$ as compare to control. Significant improvement in yield attributes of dill with the N fertilization could be ascribed to overall improvement in vigour and crop growth. The faster growth of plants evidenced from increased biomass plant ${ }^{-1}$ at successive stages of crop growth with $\mathrm{N}$ subscribe to the views that there was better availability of metabolites and nutrients, which synchronized to the demand for the growth and development of each reproductive structure of the dill plant. The present trend of increment in seed yield, straw yield and biological yield of dill with the application of $\mathrm{N}$ is in close conformity with the findings of Krishnamoorthy and Madalgari (2000); Tripathi et al. (2009); Naruka et al. (2012).

\subsubsection{Quality attributes}

Significantly higher chlorophyll content of leaves and essential oil of seed was recorded as a result of higher levels of $\mathrm{N}$ fertilization. The biological role of $\mathrm{N}$ as an essential constituent of chlorophyll in harvesting solar energy, phosphorylated compounds in energy transformations, nucleic acids in the transfer of genetic information and the regulation of cellular metabolism and of protein as structural units and biological catalysts is well known. The mark improvement in quality characters due to $\mathrm{N}$ is in close agreement with findings of Krishnamoorthy and Madalgari (2000) in ajowan.

\subsubsection{Economics}

The maximum gross return of ₹ $75220 \mathrm{ha}^{-1}$ was recorded with the spacing $50 \times 10 \mathrm{~cm}^{2}$ and $₹ 72116 \mathrm{ha}^{-1}$ was recorded with treatment of $75 \mathrm{~kg} \mathrm{~N} \mathrm{ha}^{-1}$. The maximum net return of ₹ 52323 $\mathrm{ha}^{-1}$ was recorded with the spacing $50 \times 10 \mathrm{~cm}^{2}$ and ₹ $48738 \mathrm{ha}^{-1}$ was recorded with treatment of $75 \mathrm{~kg} \mathrm{~N} \mathrm{ha}^{-1}$. The highest B:C ratio of 3.27:1 was recorded with spacing $50 \times 10 \mathrm{~cm}^{2}$ and $\mathrm{B}: \mathrm{C}$ ratio of 3.08:1 was recorded with $75 \mathrm{~kg} \mathrm{~N} \mathrm{ha}^{-1}$. These results are in the close conformity with those of Naruka et al. (2012) in ajowan crop and Meena et al. (2013) in dill crop.

\section{Conclusion}

Sowing of dill crop at spacing of $50 \times 10 \mathrm{~cm}$ and application of $75 \mathrm{~kg} \mathrm{~N} \mathrm{ha}^{-1}$ may realize for maximum production under Malwa plateau condition of Malwa region of Madhya Pradesh. Among various levels of row spacing tried, $50 \times 10 \mathrm{~cm}$ row spacing recorded significantly maximum seed yield of 15.04 $\mathrm{q}^{\mathrm{q}} \mathrm{a}^{-1}$ which was $42.56 \%$ higher as compare to row spacing of $40 \times 10 \mathrm{~cm}^{2}$. Among the various nitrogen levels tried, $75 \mathrm{~kg}$ $\mathrm{N} \mathrm{ha}^{-1}$ recorded seed yield of $14.48 \mathrm{q} \mathrm{ha}^{-1}$ which was $57.22 \%$ higher as comparison to control.

\section{References}

A.O.A.C., 1995. Official and Tentative Methods of Analysis. Association of Official Analytical Chemists International. $16^{\text {th }}$ Edn, Virginia (USA).

Bagari, S., Singh, P.P., Naruka, I.S., Rathore, S.S., Shaktawat, R.P.S., 2010. Effect of date of sowing and nitrogen levels on growth, yield and quality of fennel. Indian Journal of Horticulture. 67(4), 518-524.

DASD, 2012. Area and Production Statistics of Arecanut and Spices, (Department of Agriculture and Cooperation), Ministry of Agriculture, Government of India Calicut 673005 , Kerala, India.

Krishnamoorthy, V., Madalageri, M.B., 2000. Effect of interaction of nitrogen and phosphorus on seed and essential oil yield of ajowan (Trachyspermum ammi L.) genotypes. Journal of Spices and Aromatic Crops 9(2), 137-139.

Meena, S.S., Mehta, R.S., Meena, R.D., Meena, N.K., Singh, B., 2013. Effect of sowing time and crop geometry on growth and seed yield of dill (Anethum sowa $\mathrm{L}$ International Journal of Seed Spices 3(2), 81-84.

Mehta, R.S., Anwer, M.M., Sharma, Y.K., 2012. Effect of irrigation, nutrient levels and crop geometry on growth and yield of dill (Anethum sowa L.). Journal of Spices and Aromatic Crops 21(1), 20-24.

Naruka, I.S., Singh, P.P., Barde, M., Rathore, S.S., 2012. Effect of spacing and nitrogen levels on growth, yield and quality of ajwain (Trachyspermum ammi L. Sprague). International Journal of Seed Spices 2(1), 12-17.

Reddy, T.Y., Reddi, G.H.S., 2002. Principle of Agronomy. Kalyani Publishers, Ludhiana, 214.

Tripathi, S.M., Dwivedi, A.K., Singh, S.K., Dutta, S.D., 2009. Impact on yield of dill (Anethum graveolens L.) as influenced by nitrogen and row spacing. Annals of Horticulture 2(2), 214-216. 